\title{
Het goedkeuringsrecht voor deelnemingen in art. 2:107a (en 2:164/274) BW: Mylan/Meda revisited*
}

\author{
C. de Groot \& T.L.M. Verdoes
}

\section{Inleiding}

Art. 2:107a lid 1 Burgerlijk Wetboek (BW) bepaalt voor de naamloze vennootschap dat het bestuur de goedkeuring van de algemene vergadering nodig heeft voor besluiten 'omtrent een belangrijke verandering van de identiteit of het karakter van de vennootschap of de onderneming'. Diezelfde bepaling noemt drie besluiten die daar 'in ieder geval' onder vallen. Het onder c genoemde geval is een besluit tot:

'het nemen of afstoten van een deelneming in het kapitaal van een vennootschap ter waarde van ten minste een derde van het bedrag van de activa volgens de balans met toelichting of, indien de vennootschap een geconsolideerde balans opstelt, volgens de geconsolideerde balans met toelichting volgens de laatst vastgestelde jaarrekening van de vennootschap, door haar of een dochtermaatschappij'.

Art. 2:107a lid 1 onder c BW lijkt op art. 2:164/274 lid 1 onder e BW, dat in de zogenoemde structuurregeling voor 'grote' naamloze vennootschappen en 'grote' besloten vennootschappen (structuurvennootschappen) bepaalt dat het bestuur de goedkeuring van de raad van commissarissen nodig heeft voor besluiten omtrent:

'het nemen van een deelneming ter waarde van ten minste een vierde van het bedrag van het geplaatste kapitaal met de reserves volgens de balans met toelichting van de vennootschap, door haar of een afhankelijke maatschappij in het kapitaal van een andere vennootschap, alsmede het ingrijpend vergroten of verminderen van zulk een deelneming'.

Dortmond schrijft over de waarde van de deelneming in art. 2:164/274 BW, dat daaronder 'in het algemeen zal moeten worden verstaan de prijs die voor de deelneming wordt betaald'. ${ }^{1}$ Klaassen wijst erop dat het nemen of afstoten van een deelneming vooral van belang is "wanneer niet de "juiste" prijs wordt betaald of

* De auteurs danken dr. M.L. (Maaike) Lycklama à Nijeholt (Kenniscentrum Business Innovation, Hogeschool Rotterdam en afdeling Ondernemingsrecht, Universiteit Leiden) voor haar commentaar op een eerdere versie van dit artikel.

1 Van der Heijden/Dortmond, Handboek voor de naamloze en de besloten vennootschap, Deventer: Kluwer 2013, p. 592. 
verkregen voor de deelnemingen'. ${ }^{2}$ Zij verwijst naar Brink, die schrijft dat het criterium in art. 2:107a lid 1 onder c BW niet zonder meer duidelijk is: 'De woorden "het bedrag van de activa" in het voorgestelde lid 1 sub c kan immers ook worden gelezen als alleen de actiefposten op de balans', met als toevoeging: 'Het begrip "vermogen" was naar mijn mening duidelijker geweest." Ook Josephus Jitta merkt op dat de vergelijking in art. 2:107a lid 1 onder c BW tussen enerzijds de waarde van de deelneming en anderzijds het bedrag van de activa volgens de balans of de geconsolideerde balans 'een vergelijking tussen appels en peren' is. Dit komt bijvoorbeeld naar voren bij het afstoten van een deelneming: de waarde van de deelneming wordt dan bepaald op stand alone-basis, maar in de (geconsolideerde) jaarrekening is de deelneming volledig verwerkt, dus voor een hogere waarde. ${ }^{4}$ Dit artikel gaat vanuit zowel een juridisch als een bedrijfswetenschappelijk perspectief in op deze kwestie. De kwestie is voor de praktijk relevant. Dit bleek in 2016, toen de Vereniging van Effectenbezitters (VEB) zich op het standpunt stelde dat Mylan N.V. (hierna: Mylan) haar poging om Meda Aktienbolag (hierna: Meda) over te nemen aan de algemene vergadering diende voor te leggen. Dit leidde tot een briefwisseling tussen de VEB en Mylan, waarin de VEB en Mylan tegengestelde standpunten innamen over de interpretatie van art. 2:107a lid 1 onder c BW. ${ }^{5}$ In dit artikel worden die verschillende interpretaties van art. 2:107a BW uiteengezet. Paragraaf 2 gaat in op de wetsgeschiedenis van art. 2:107a BW, en betrekt daarbij de wetsgeschiedenis van het oudere art. 2:164/274 BW. Paragraaf 3 bespreekt kort de Mylan/Meda-casus. In paragraaf 4 en 5 komen de argumenten van de VEB en Mylan aan bod. Die argumenten worden in paragraaf 4 besproken tegen de achtergrond van het hoofdbeginsel in art. 2:107a BW, dat het goedkeuringsrecht van de algemene vergadering betrekking heeft op besluiten die leiden tot 'een belangrijke verandering van de identiteit of het karakter van de vennootschap of de onderneming'. Paragraaf 5 gaat concreet in op onderdeel c van art. 2:107a BW. Paragraaf 6 bevat de conclusie en doet een voorstel tot verbetering.

\section{Art. 2:107a lid 1 onder c en 2:164/274 lid 1 onder e BW}

\subsection{Algemeen}

Art. 2:107a BW dateert uit 2004; art. 2:164/274 BW dateert in zijn oorspronkelijke vorm uit 1971. In de ontstaansgeschiedenis van deze bepalingen is een aan-

2 A.G.H. Klaassen, Bevoegdheden van de algemene vergadering van aandeelhouders, Deventer: Kluwer 2007, p. 196.

3 M. Brink, De Korenschoof revisited, in: F.J.P. van den Ingh e.a. (red.), Met een zekere stijl. Gedenkbundel ter ere van mr. Justus Voûte, Den Haag: Boom Juridische uitgevers 2002, p. $113-125$ (p. 120).

4 M.W. Josephus Jitta, Schuitje varen, theetje drinken, varen wij door het polderland. De uitbreiding van de bevoegdheden van de aandeelhoudersvergadering, Ondernemingsrecht 2002, p. 74.

5 Deze briefwisseling is opgenomen op de website van de VEB (www.veb.net): brief van 26 februari 2016 van de VEB aan Mylan, brief (reactie) van 29 februari 2016 van Mylan aan de VEB, brief van 10 maart 2016 van de VEB aan Mylan (waarin de argumenten van de VEB het meest gedetailleerd uiteen worden gezet), en brief van 6 april 2016 van de VEB. 
tal bronnen van belang: het rapport van de commissie-Verdam uit 1964, het daarop volgende advies van de Sociaal-Economische Raad (SER) over de herziening van het ondernemingsrecht uit 1969, de parlementaire geschiedenis bij art. 2:164/274 BW (beginnend met het rapport van de Commissie Vennootschapsrecht over het advies van de SER) en de parlementaire geschiedenis bij art. 2:107a BW.

\subsection{De ontstaansgeschiedenis van art. 2:164 lid 1 onder e/2:274 lid 1 onder e BW}

Op 8 april 1960 stelde de minister van Justitie een commissie in die tot taak had voorstellen te doen voor aanpassing van het ondernemingsrecht. De voorzitter van deze commissie was P.J. Verdam; daarom wordt de commissie ook wel aangeduid als de commissie-Verdam. De commissie-Verdam bracht haar rapport uit op 26 november 1964. Dit was het rapport 'Herziening van het ondernemingsrecht'. ${ }^{6}$ In dit rapport stelde de commissie (als voorloper van het huidige art. 2:164/274 BW) de volgende bepaling voor (als art. 50j Wetboek van Koophandel $(\mathrm{WvK}))^{7}$

'De akte van oprichting vermeldt, welke besluiten slechts op voorstel of met toestemming van commissarissen kunnen worden genomen. Tot deze besluiten behoren in ieder geval die tot: (...) d. verwerving van ten minste het vierde gedeelte van het geplaatste kapitaal van een andere vennootschap, alsmede wijziging in de omvang van een zodanig aandelenbezit; (...).'

Deze bepaling maakte deel uit van een serie bepalingen die uiteindelijk de structuurregeling zijn geworden. In het rapport van de commissie-Verdam ging het nog om de volgende vennootschappen: beursgenoteerde naamloze vennootschappen en 'andere naamloze vennootschappen, die tengevolge van kapitaaldeelneming rechtstreeks of middellijk een vennootschap, [als hiervoor bedoeld], beheersen'. ${ }^{8}$ De bepaling is bijzonder eenvoudig. Het gaat om het verwerven van een kapitaalverschaffing ter grootte van ten minste $25 \%$ van het geplaatste kapitaal van de vennootschap waarin wordt deelgenomen (de 'andere' vennootschap). Al even eenvoudig is de toelichting bij deze bepaling: art. 50j WvK gaat over 'gewichtige besluiten van andere organen, die niet zonder toestemming van commissarissen kunnen worden genomen', omdat de raad van commissarissen 'als vertrouwenscollege van alle groepen' daaraan zijn instemming moet geven. ${ }^{9}$

6 Herziening van het ondernemingsrecht. Rapport van de Commissie ingesteld bij beschikking van de Minister van Justitie van 8 april 1960, Den Haag: Staatsuitgeverij 1968. Over de commissieVerdam: Van der Heijden/Dortmond 2013, p. 18-19.

7 Herziening van het ondernemingsrecht, p. 117; ook te vinden in: Advies inzake de herziening van het ondernemingsrecht, SER, www.ser.nl (publicaties, SER-adviezen, 1960-1969, 1969/14, p. 31-32).

8 Herziening van het ondernemingsrecht, p. 116; ook te vinden in: Advies inzake de herziening van het ondernemingsrecht, p. 30.

9 Herziening van het ondernemingsrecht, p. 125-126. 
De SER steunde dit voorstel, 'zij het (...) dat het hem gewenst voorkomt in enkele onderdelen van deze opsomming nadere begrenzingen aan te brengen'. ${ }^{10}$ De SER herformuleerde het voorstel van de commissie-Verdam door onder d een zinsdeel toe te voegen en een nieuwe letter e te introduceren: ${ }^{11}$

'(...) d. verwerving van ten minste vijfentwintig procent van het geplaatste kapitaal van een andere vennootschap alsmede wijziging in de omvang van een zodanig aandelenbezit, indien de totale activa van die andere vennootschap meer dan vijftien procent bedragen van de geconsolideerde activa van de onderneming;

e. verwerving of vervreemding van ten minste tien procent van het geplaatste kapitaal van een andere vennootschap, indien de onderneming ten minste vijfentwintig procent van het geplaatste kapitaal van die vennootschap rechtstreeks of middel[l]ijk houdt en de totale activa van die vennootschap meer dan vijftien procent bedragen van de geconsolideerde activa van de onderneming; (...).' (cursivering in origineel)

De SER gaf geen expliciete motivering bij de voorgestelde tekst. In dit voorstel gaat de bepaling onder d over het verwerven of wijzigen van een kapitaalverschaffing in een andere vennootschap, en gaat de bepaling onder e over het vergroten of verkleinen van zo'n kapitaalverschaffing met ten minste $10 \%$. De toevoeging onder d bevat onder meer een waardecriterium: de raad van commissarissen speelt slechts een rol als het balanstotaal aan de activazijde van de andere vennootschap meer dan $15 \%$ bedraagt van het geconsolideerde balanstotaal aan de activazijde van de deelnemende vennootschap. In de bepaling onder e is de rol van de raad van commissarissen afhankelijk van drie elementen: (1) de deelnemende vennootschap heeft al een kapitaalverschaffing van ten minste $25 \%$ in een andere vennootschap; (2) de deelnemende vennootschap vergroot of verkleint die deelneming met ten minste 10\%; en (3) het balanstotaal aan de activazijde van die andere vennootschap moet meer dan $15 \%$ bedragen van het geconsolideerde balanstotaal aan de activazijde van de deelnemende vennootschap. Opvallend is dat zowel onder d als onder e de term 'geconsolideerde activa' (in plaats van activa sec) wordt gebruikt. Dit komt wellicht voort uit de veronderstelling dat een beursgenoteerde vennootschap en een vennootschap die een beursgenoteerde vennootschap beheerst (vrijwel) altijd een geconsolideerde balans zullen opstellen.

Het hierop volgende wetsvoorstel leidde tot introductie van de structuurregeling. Een belangrijk onderscheid met de beide eerdere voorstellen is dat de structuurregeling niet is gericht op beursgenoteerde vennootschappen, maar op 'grote' ven-

10 Advies inzake de herziening van het ondernemingsrecht, p. 25.

11 Advies inzake de herziening van het ondernemingsrecht, p. 34. 
nootschappen. Het voorgestelde art. $52 \mathrm{n}$ WvK (voorloper van het huidige art. 2:164/274 BW) luidde als volgt: ${ }^{12}$

'Aan de goedkeuring van de raad van commissarissen zijn onderworpen de besluiten van het bestuur tot: (...) e. rechtstreekse of middellijke deelneming in het kapitaal van een andere vennootschap, waarvan de waarde ten minste gelijk is aan het bedrag van een vierde gedeelte van het geplaatste kapitaal met de reserves der deelnemende vennootschap volgens haar balans met toelichting, alsmede een ingrijpende wijziging in de omvang van een zodanige deelneming; (...).'

De tekst van deze bepaling was voorbereid door de Commissie Vennootschapsrecht. De commissie voegde de letters d en e uit het SER-voorstel samen tot één bepaling. In die bepaling nam de commissie met name afstand van het element in het SER-voorstel dat het balanstotaal aan de activazijde van de 'andere' vennootschap in omvang meer dan $15 \%$ moet bedragen van het geconsolideerde balanstotaal aan de activazijde van de deelnemende vennootschap. De commissie voerde daarvoor twee argumenten aan.

Als inhoudelijk argument stelde de commissie dat de koppeling van de waarde van de activa van de 'andere' vennootschap aan de waarde van de (geconsolideerde) activa van de deelnemende vennootschap niet voor de hand ligt, omdat de waarde van de (geconsolideerde) activa van de deelnemende vennootschap afhankelijk is van toevalligheden zoals de voorraadpositie. Daarom bepleitte de commissie een koppeling tussen de waarde van de deelneming in de 'andere' vennootschap en de hoogte van het geplaatste kapitaal en de reserves van de deelnemende vennootschap: 'Veel bevredigender is om als maatstaf de verhouding van de waarde van de deelneming (...) tot het eigen vermogen der vennootschap te nemen. ${ }^{13}$

Als technisch argument voerde de commissie aan dat de verwijzing naar de totale activa van de 'andere' vennootschap en de geconsolideerde activa van de deelnemende vennootschap afwijkt van de terminologie die centraal staat in de structuurregeling. In die terminologie valt een vennootschap onder het bereik van de structuurregeling als zij voldoet aan het basisvereiste dat haar geplaatste kapitaal en haar reserves (de belangrijkste onderdelen van het eigen vermogen) ten minste (naar de huidige termen) $€ 16$ miljoen bedragen: 'Dit sluit ook aan bij het criterium dat voor de toepasselijkheid van de regeling is gesteld. Het eigen vermogen - niet de som van de activa - is het criterium. ${ }^{14}$

12 Handelingen II 1969/70, 10751, Wijziging van het Wetboek van Koophandel (Voorzieningen met betrekking tot de structuur der naamloze en besloten vennootschap), nr. 2, ontwerp van wet (20 juli 1970).

13 Handelingen II 1969/70, 10751, Wijziging van het Wetboek van Koophandel (Voorzieningen met betrekking tot de structuur der naamloze en besloten vennootschap), nr. 4, bijlage bij de MvT: Rapport van de Commissie Vennootschapsrecht betreffende het advies van de Sociaal-Economische Raad inzake de herziening van het ondernemingsrecht, p. 24.

Ibid. 
De parlementaire geschiedenis bij het wetsvoorstel ging hier niet verder op in. Het wetsvoorstel resulteerde in de wet van 6 mei 1971, houdende wijziging van het Wetboek van Koophandel (Voorzieningen met betrekking tot de structuur der naamloze en besloten vennootschap), Stb. 1971, 289. De huidige tekst van art. 2:164/274 lid 1 onder e BW is tot stand gekomen door de wet van 25 maart 1987, houdende toepassing van de structuurregeling indien een naamloze of besloten vennootschap of dochtermaatschappij daarvan vennote is van een commanditaire vennootschap of vennootschap onder firma, Stb. 1987, 112. In plaats van 'rechtstreekse of middellijke deelneming' spreekt de tekst nu over het nemen van een deelneming door de vennootschap 'of een afhankelijke maatschappij'. De woorden deelneming 'waarvan de waarde ten minste gelijk is aan' komen terug als 'deelneming ter waarde van ten minste'.

Overigens worden in art. 2:164/274 onder $\mathrm{f}$ BW ook andere wijzen van verandering in het arsenaal aan bedrijfsmiddelen aan goedkeuring onderworpen: 'investeringen' ${ }^{15}$ Investeringen van een bepaalde omvang wijzigen de omvang en/of samenstelling van de economische beschikkingsmacht over de bedrijfsmiddelen, het kasgenererend vermogen daarvan en de daarbij gepaard gaande risico's, en daarmee de waarde (en levensvatbaarheid) van de onderneming. Dit is uitermate belangrijk voor de stakeholders van een vennootschap. Deze overweging ligt waarschijnlijk aan de basis van het goedkeuringsvereiste. Ook het nemen (en vergroten of verminderen) van een deelneming is een investeringsbeslissing. Investeringen kunnen direct van aard zijn - de aankoop van activa - of indirect van aard de overname van een deelneming waarmee de activa van deze deelneming worden verkregen.

Het relateren van de waarde van de deelneming en de investering (genoemd onder e en $f$ van art. 2:164/274 lid 1 BW) aan het eigen vermogen is veeleer een praktisch en formeel criterium en geen theoretisch en materieel criterium. Dit blijkt uit de motivering van de Commissie Vennootschapsrecht, dat sprake dient te zijn van een meer stabiele maatstaf. Niet duidelijk wordt waarom de maatstaf stabiel moet zijn. ${ }^{16}$ Er bestaat accountingtechnisch en financieringstheoretisch geen relatie tussen de investering en de omvang van het eigen vermogen. ${ }^{17}$ Ook het technische 'toepasselijkheidsargument' overtuigt niet. Een maatstaf voor de indeling in een regime wordt van toepassing verklaard op een investeringsbeslissing: dit is niet zonder meer logisch.

15 Een vergelijkbare bepaling ontbreekt in art. 2:107a BW. Josephus Jitta 2002, p. 74, merkt op dat daardoor de structuur van de transactie (verwerven van bedrijfsmiddelen al dan niet via een deelneming) van invloed is op de vraag of de algemene vergadering haar goedkeuring moet verlenen.

16 Bovendien verandert het eigen vermogen ook door aandelenemissies en winstinhoudingen.

17 Een investeringsbeslissing dient onafhankelijk van de vermogensstructuur te worden genomen. De waarde van de onderneming is in beginsel onafhankelijk van de vermogensstructuur. Zie R.A. Brealey, S.C. Myers \& A.J. Marcus, Fundamentals of corporate finance (9de druk), McGraw-Hill 2017, p. 282-283 en hoofdstuk 16. 


\subsection{De ontstaansgeschiedenis van art. 2:107a lid 1 onder c BW}

Art. 2:107a BW is ingevoerd door de wet van 9 juli 2004 tot wijziging van boek 2 van het Burgerlijk Wetboek in verband met aanpassing van de structuurregeling, Stb. 2004, 370. In deze wetswijziging, die betrekking had op de structuurregeling, is art. 2:107a BW, dat geen deel uitmaakt van de structuurregeling, als het ware 'meegenomen'. Het oorspronkelijke wetsvoorstel bevatte de volgende tekst van art. 2:107a lid 1 onder c BW: ${ }^{18}$

'c. het nemen of afstoten van een deelneming in het kapitaal van een vennootschap ter waarde van ten minste een derde van het bedrag van de activa volgens de geconsolideerde balans met toelichting volgens de laatst vastgestelde jaarrekening van de vennootschap, door haar of een dochtermaatschappij'.

De memorie van toelichting motiveerde de keuze om, in afwijking van art. 2:164/274 lid 1 onder e BW, niet aan te sluiten bij 'het bedrag van het geplaatste kapitaal met de reserves', maar bij 'het bedrag van de activa' als volgt:

'Het balanstotaal, waarmee doorgaans wordt aangeduid het geheel van de actief- respectievelijk passiefposten op de balans (artikel 2:364-376 BW) omvat naast het eigen vermogen ook voorzieningen en lang- en kortlopende schulden. Het geeft een goed inzicht in de waarde van de met de vennootschap verbonden onderneming en is daarom geschikt als criterium.' ${ }^{19}$

Deze tekst van art. 2:107a lid 1 onder c BW verwees slechts naar het bedrag van de activa volgens de geconsolideerde balans. Dit is aangepast door de tweede nota van wijziging, waardoor nu zowel het bedrag van de activa volgens de balans met toelichting als het bedrag van de activa volgens de geconsolideerde balans (indien de vennootschap een geconsolideerde balans opstelt) wordt genoemd. De reden hiervoor is eenvoudig:

'Niet geheel uit te sluiten valt evenwel de situatie dat geen geconsolideerde balans voorhanden is, omdat de deelneming niet behoeft te worden geconsolideerd en de vennootschap evenmin beschikt over andere deelnemingen dan wel dochtermaatschappijen die op grond van artikel 2:406 BW tot de opstelling van de geconsolideerde balans dwingen. ${ }^{20}$ met aanpassing van de structuurregeling, nr. 2, voorstel van wet (8 januari 2002).

19 Handelingen II 2001/02, 28179, Wijziging van boek 2 van het Burgerlijk Wetboek in verband met aanpassing van de structuurregeling, nr. 3, MvT (8 januari 2002), p. 19; vgl. Handelingen II 2001/02, 28179, Wijziging van boek 2 van het Burgerlijk Wetboek in verband met aanpassing van de structuurregeling, nr. 5, NV II (17 juni 2002), p. 19.

20 Handelingen II 2002/03, 28179, Wijziging van boek 2 van het Burgerlijk Wetboek in verband met aanpassing van de structuurregeling, nr. 31, tweede nota van wijziging (28 augustus 2003), p. 5. 


\subsection{Overzicht van de maatstaven naar aanleiding van de wetshistorie (art. 2:164/264} en $107 a$ BW)

Uit het voorgaande blijkt dat de verschillende regelingen en voorstellen in grote lijnen meanderen om verschillende maatstaven:

- de deelneming sec (het rapport van de commissie-Verdam);

- de waarde van de activa van de deelneming gerelateerd aan de waarde van de activa volgens de geconsolideerde balans (het advies van de SER);

- de waarde van de deelneming gerelateerd aan de waarde van het eigen vermogen volgens de balans van de deelnemende vennootschap (art. 2:164/274 BW); en

- de waarde van de deelneming gerelateerd aan de waarde van de activa volgens de balans of de geconsolideerde balans van de deelnemende vennootschap (art. 2:107a BW).

Er is sprake van een ratjetoe aan maatstaven, waarbij de motivering veelal ontbreekt. Er bestaat geen duidelijke visie over de criteria die ten grondslag liggen aan het goedkeuringsrecht. Dit komt ook in de weergave van de discussie tussen Mylan en de VEB in paragraaf 4 en 5 aan de orde.

\subsection{Afronding}

Art. 2:107a lid 1 onder c BW en art. 2:164/274 lid 1 onder e BW lijken op elkaar, maar verschillen tegelijkertijd aanmerkelijk. Een overeenkomst is dat het zowel in art. 2:107a BW als in art. 2:164/274 BW gaat om goedkeuring door de algemene vergadering respectievelijk de raad van commissarissen van de deelnemende vennootschap zelf, én om goedkeuring door de algemene vergadering respectievelijk de raad van commissarissen van een moedervennootschap voor deelnemingen door een dochtervennootschap (in art. 2:107a BW aangeduid als dochtermaatschappij en in art. 2:164/274 BW aangeduid als afhankelijke maatschappij). Verschillen zijn dat:

- art. 2:107a BW geldt voor (alle) naamloze vennootschappen, en art. 2:164/274 BW geldt voor zowel naamloze vennootschappen als besloten vennootschappen, maar alleen als deze vennootschappen structuurvennootschappen zijn;

- $\quad$ art. 2:107a BW gaat over deelnemingen die een waarde hebben van ten minste een derde van de activa van de deelnemende (moeder)vennootschap, en art. 2:164/274 BW gaat over deelnemingen die een waarde hebben van ten minste $25 \%$ van het geplaatste kapitaal plus de reserves van de deelnemende (moeder)vennootschap; en

- $\quad$ art. 2:107a BW het heeft over deelnemingen met een waarde van ten minste een derde afgezet tegen de balans van de deelnemende (moeder)vennootschap, waarbij de balans wordt vervangen door de geconsolideerde balans als die er is, en art. 2:164/274 BW het alleen heeft over deelnemingen met een waarde van ten minste $25 \%$ afgezet tegen de balans van de deelnemende (moeder)vennootschap, zonder dat de balans wordt vervangen door de geconsolideerde balans als die er is. 


\section{De casus Mylan/Meda}

Mylan is een in 1961 opgerichte Amerikaanse vennootschap die zich heeft toegelegd op de productie, ontwikkeling en distributie van vooral generieke receptloze (over the counter) medicijnen. ${ }^{21}$ Sinds 1973 was de vennootschap zowel in de Verenigde Staten als in Israël beursgenoteerd. In 2014 volgde een strategische zet, waarbij de overname van de activiteiten van Abbott werd aangegrepen om de zetel van Mylan te verplaatsen naar Nederland door middel van een (omgekeerde) driehoeksfusie. Deze zetelverplaatsing had twee doelen: een vermindering van de afdracht van vennootschapsbelasting, die in de Verenigde Staten hoger is dan in Nederland, en de benutting van het als gunstig bekend staande Nederlandse klimaat van beschermingsconstructies. ${ }^{22}$ Op 10 februari 2016 kondigde Mylan de overname van Meda aan. Meda is een Zweedse onderneming op het gebied van healthcare. Het bod bedroeg \$7,2 miljard. Het bod zou voor $80 \%$ in cash worden betaald en voor $20 \%$ in aandelen. Inclusief de over te nemen nettoschuld van Meda van \$2,7 miljard bedroeg het bod \$ 9,9 miljard. Het overnamebericht meldde: 'The Offer is not subject to approval by Mylan shareholders and is not subject to any financing conditions. ${ }^{23}$ Hiertegen kwam de VEB in het geweer. Zij stelde dat de waarde van de deelneming te laag en de waarde van de activa op de geconsolideerde balans te hoog werden weergegeven, waardoor de verhouding onder de een derde kwam, zodat de overname niet aan de algemene vergadering voorgelegd hoefde te worden. ${ }^{24}$

\section{Algemene bedrijfseconomische opmerkingen over art. 2:107a BW}

\subsection{De onderneming: entiteit van bedrijfsmiddelen}

Een onderneming is (bedrijfseconomisch) te omschrijven als een organisatie van mensen die bedrijfsmiddelen bijeenbrengen en converteren, gericht op verwachte economische voordelen. ${ }^{25}$ De onderneming is te typeren als een samenstel van

21 Zie www.mylan.nl/nl-nl/over-ons/onze-geschiedenis.

22 Mylan wijkt via 'papieren transactie' uit naar Nederland, Het Financieele Dagblad 30 juli 2014; Bieder Mylan dekt zichzelf in tegen overname, Het Financieele Dagblad 9 april 2015.

23 'Mylan to acquire Meda', zie http://medatransaction.mylan.com/.

24 De VEB kwam hierbij met verschillende berekeningswijzen van de waarde van de deelneming en van de geconsolideerde activa. Bij de laatste berekeningen gaat het om de weergave van de geconsolideerde activa op de laatst vastgestelde jaarrekening zoals in art. 2:107a lid 1 onder c BW wordt aangegeven. Die loopt achter bij de feitelijke - economische - beschikkingsmacht over de activa, waardoor de berekening moet plaatsvinden met verouderde gegevens. Dit bezwaar tegen art. 2:107a lid 1 onder c BW wordt ook opgemerkt door Josephus Jitta 2002, p. 74.

25 Vgl. voor deze omschrijving J.L. Bouma, Leerboek der bedrijfseconomie, deel 1A, Wassenaar: Delwel 1968, p. 22. Aan de omschrijving is 'verwachte' toegevoegd omdat er geen zekerheid bestaat dat een onderneming waarde creëert, of in de toekomst winsten behaalt. Volgens C.N. Pitelis \& D.J. Teece, The (new) nature and essence of the firm, European Management Review 2009, p. 5-15, is de 'essence and nature' van een onderneming gelegen in het feit dat de netto contante waarde van een investering onzeker is. 
bedrijfsmiddelen. ${ }^{26}$ De (gecombineerde) specifieke eigenschappen van deze bedrijfsmiddelen leveren het onderscheidend vermogen op van de onderneming. ${ }^{27}$ Deze unieke identiteit komt tot uitdrukking in verschillende dimensies: businessmodel, core competences, corporate governance, (mate van) duurzaamheid, marktpositionering, missie, productassortiment, reputatie, risicoprofiel, strategie, track record, enzovoort. Ook de jaarrekening met een balans, winst-enverliesrekening en kasstroomoverzicht is een weergave van hoe de onderneming zich naar buiten manifesteert. ${ }^{28}$ In het samenstel van de bedrijfsmiddelen en de aanspraken (in accountingterminologie: de activa en de verplichtingen) die daarop rusten, vinden voortdurend veranderingen plaats. Hierdoor veranderen de omvang en samenstelling van de bedrijfsmiddelen van de onderneming. De identiteit van een onderneming evolueert hierdoor continu. ${ }^{29}$

\subsection{De identiteit en het karakter van de vennootschap en de onderneming}

Het hoofdbeginsel van art. 2:107a lid 1 BW spreekt over een belangrijke verandering van de identiteit of het karakter van de vennootschap of de onderneming. Daarvan is in drie concrete situaties in ieder geval sprake: (a) bij de overdracht van de onderneming, (b) bij het aangaan of verbreken van duurzame samenwerking met een andere vennootschap, en (c) bij het nemen of afstoten van een deelneming. In onderdeel a staat de (vrijwel) gehele overdracht van de onderneming aan een derde centraal. Deze bepaling is het meest duidelijk omdat in dit geval de identiteit en het karakter van de onderneming worden aangetast. Bij overdracht van de gehele onderneming - bijvoorbeeld bij verkoop - wordt de resterende vennootschap een kas- of beleggingsonderneming. In onderdeel b staat centraal het aangaan dan wel verbreken van duurzame samenwerking van de vennootschap met een andere vennootschap indien dit van ingrijpende betekenis voor de vennootschap is. Dit met ingrijpende betekenis uitgedrukte materialiteitsprincipe is iets anders geformuleerd dan de belangrijke verandering in het hoofdbeginsel van art. 2:107a lid 1 BW. Dat is ook het geval in onderdeel c: het nemen of afstoten van een deelneming. Een belangrijk kenmerk van een deelneming is immers het duurzaam verbonden zijn met een andere rechtspersoon (vergelijk art. 2:24c BW). In onderdeel c wordt dit echter gekoppeld aan de omvang van de activa, en niet eenop-een aan een belangrijke verandering van de identiteit of het karakter. In onderdeel a lijkt het samenstel van de bedrijfsmiddelen centraal te staan; onder-

26 De 'resource-based theory of the firm' is hierop gebaseerd; zie B. Wernerfelt, A resource-based view of the firm, Strategic Management Journal (5) 1984, afl. 2, p. 171-180.

27 "Hard to imitate intra-firm resources and capabilities, as well as "relatively impregnable bases" and the overall "business model", can also help shape a firm's "distinct identity" and therefore engender a "firm differentiation" barrier to entry', zie C.N. Pitelis, The co-evolution of organizational value capture and creation, Organization Studies (30) 2009, afl. 10, p. 1125-1126.

28 Zie M. Corbey \& W. van Hulst, Bedrijfseconomie, grondslagen en perspectieven, Den Haag: Sdu Uitgevers 2011, p. 182: 'De accounting houdt er nauwelijks een uitgesproken visie op de onderneming op na: de onderneming is de onderneming zoals deze bestond gedurende de verslagperiode en zij manifesteert zich uitsluitend door financieel-economische grootheden.' De geconsolideerde balans toont o.a. de bedrijfsmiddelen of activa van de groep van ondernemingen waarover zij de economische beschikkingsmacht heeft.

29 Nokia is bijv. geëvolueerd van een pulpfabrikant in een telecommunicatieonderneming. 
deel $b$ staat door de gekozen formulering iets verder af van het hoofdbeginsel van art. 2:107a lid 1 BW. In onderdeel $c$ is alleen nog de (financieel-economische) omvang van de waarde van de deelneming relevant.

\subsection{De identiteit en het karakter van Mylan}

'Mylan is a global healthcare company focused on making high quality medicines available to everyone who needs them. ${ }^{30}$ De missie van Mylan is 'setting new standards in healthcare. Working together around the world to provide 7 billion people access to high quality medicine. ${ }^{31}$ De overname van Medan lijkt Mylan een betere geografische toegang en spreiding te geven, met aanvullende medicijnen. De combinatie creëert een wereldwijd netwerk van uiteenlopende generieke en voornamelijk receptloze medicijnen. Meda zorgt voor kritische massa op sommige markten en kan dienen als een springplank in opkomende markten, waardoor een meer gediversificeerde product/marktportefeuille ontstaat met een bepaalde schaalgrootte. ${ }^{32}$ Beide ondernemingen werken bovendien al met elkaar samen. De risico's van de overname lijken hiermee beperkt, sterker nog: door de diversificatie kan het ondernemingsrisico na de integratie verminderen. In haar reactie op het standpunt van de VEB meldt Mylan dan ook het volgende:

'This transaction complements Mylan's breadth, scale and diversity to drive durable growth for the long term and is entirely consistent with Mylan's mission and long-standing strategy of pursuing growth through organic and inorganic opportunities. ${ }^{33}$

De VEB geeft enerzijds aan geen inhoudelijk oordeel te hebben over de overname, ${ }^{34}$ maar in de brief van 10 maart 2016 voert zij aan dat, hoewel sprake lijkt te zijn van een strategic fit, toch sprake is van een wijziging van de identiteit of het karakter van de vennootschap. Hierbij valt bij de uitgewisselde argumenten op dat Mylan vooral strategische argumenten en de VEB voornamelijk financiële argumenten aanvoert om de eigen stellingname te onderbouwen. De overname van Meda voor \$7,2 miljard wordt voor $80 \%$ in contanten en voor $20 \%$ in aandelen betaald. De VEB wijst erop dat dit leidt tot een (door Mylan aan te gaan) overbruggingskrediet van \$5,7 miljard. De schuld van Mylan (op dat moment \$12,5 miljard) gaat hierdoor met ongeveer $50 \%$ omhoog. Dit leidt tot een uitholling van de solvabiliteit en de liquiditeit. ${ }^{35}$ De VEB geeft hierbij aan dat zowel onderdeel b

Zie www.mylan.com/en/company.

Zie www.mylan.com/en/careers/life-at-mylan.

Zie www.generics-bulletin.com/media/1053/gen-sample-article-19-2-16.pdf.

Brief van 29 februari 2016 van Mylan aan de VEB: www.veb.net/media/2445/letter-from-mylanconcerning-shareholders-approval.pdf.

Mylan moet langs haar aandeelhouders, Effect 2016, afl. 3, p. 14.

In wezen is dit nog een onderschatting, omdat op de geconsolideerde balans niet alleen de extra schulden voortkomend uit de overname worden opgenomen, maar bij consolidatie ook de schulden van Meda bij de schulden op de geconsolideerde balans tot uitdrukking worden gebracht (zie par. 5). Dit argument speelt ook een rol bij het bepalen van de waarde van de deelneming (zie eveneens par. 5). 
als onderdeel c van art. 2:107a BW louter in financiële termen (de financial exposure) en niet in strategische zin is geformuleerd. Bovendien voert de VEB aan dat deze slechtere solvabiliteit en liquiditeit gevolgen kunnen hebben voor de positie, activiteiten en strategie van de onderneming, dus toekomstige strategische consequenties heeft - naast de onmiddellijke financieel-economisch ingrijpende verandering van de identiteit of het karakter. Een onderneming met een slechte solvabiliteit en liquiditeit schroeft wellicht de investeringen en de uitgaven aan research \& development terug. Ook dit kan op termijn leiden tot een verandering van de identiteit en het karakter.

\section{Concrete bedrijfseconomische opmerkingen over art. 2:107a lid 1 onder c BW}

\subsection{Inleiding}

In onderdeel c van art. 2:107a lid 1 BW wordt de waarde van de deelneming gerelateerd aan de hoogte van de activa op de enkelvoudige balans of de geconsolideerde balans. Op beide aspecten wordt hierna ingegaan.

\subsection{De enkelvoudige balans en de geconsolideerde balans}

Vennootschappen die opereren als economische eenheid en organisatorisch zijn verbonden (vergelijk art. 2:24b BW), dienen naast een enkelvoudige balans een geconsolideerde balans op te stellen. Een enkelvoudige balans is de balans van een afzonderlijke juridische entiteit. Hierop zijn de activa, verplichtingen en het eigen vermogen van die entiteit opgenomen. De activa op de enkelvoudige balans van een moedervennootschap die als houdstervennootschap optreedt, bevatten veelal slechts de post deelnemingen; eventueel verschijnt ook een post goodwill. ${ }^{36}$ Indien elk van de tot een groep behorende vennootschappen een afzonderlijke balans zou opstellen, ontstaat weinig inzicht in de samenstelling van het vermogen van de groep als geheel. Een beter inzicht in de omvang en samenstelling van het groepsvermogen ontstaat als de activa en verplichtingen van die afzonderlijke entiteiten worden geïntegreerd. De activa, verplichtingen en het eigen vermogen van de groep worden dan weergegeven alsof zij één entiteit voorstelt, zodat inzicht ontstaat in de economische beschikkingsmacht over de bedrijfsmiddelen van de economische eenheid waartussen een organisatorisch verband bestaat. De geconsolideerde balans is een economische en niet een juridische weergave van de groep. Bij het opstellen van de geconsolideerde balans wordt de post deelnemingen in de balans van de moedervennootschap vervangen door de achterliggende activa en verplichtingen van die deelnemingen; indien de deelneming tegen kostprijs wordt gewaardeerd, komt tevens de goodwill tot uitdrukking. Op de geconsolideerde balans komt in beginsel geen post deelnemingen in groepsmaatschappijen meer voor. De activa op de geconsolideerde balans worden dan ook niet

36 Goodwill is het verschil tussen de koopprijs en de nettovermogenswaarde van de deelneming. Vgl. A.N. Labohm e.a., Waardering van ondernemingen in de juridische praktijk, Zutphen: Uitgeverij Paris 2017, p. 48. Het al dan niet verschijnen van de goodwill op de enkelvoudige balans is afhankelijk van de wijze van waardering van de deelneming, zie par. 5.3. 
zozeer door de waarde van de deelnemingen beïnvloed, maar door de achterliggende activa en verplichtingen van die deelnemingen, alsmede (eventueel) de goodwill.

\subsection{De waarde en waarderingsgrondslagen van een deelneming in de enkelvoudige balans}

Van een deelneming is sprake als een vennootschap kapitaal verschaft teneinde duurzaam verbonden te zijn met een andere rechtspersoon ten behoeve van de eigen werkzaamheid (art. 2:24c BW). Bij de waardering van een deelneming kan onderscheid worden gemaakt tussen directe (rechtstreekse) waardering van de aandelen en indirecte (afgeleide) waardering van de onderliggende activa, verplichtingen en vermogensposities die door die aandelen worden vertegenwoordigd. ${ }^{37}$ Er bestaan vijf mogelijke waarderingsgrondslagen van een deelneming:

- directe (rechtstreekse) waardering van een deelneming op basis van:

a de aanschafprijs;

b de reële waarde; of

c de actuele waarde;

- indirecte (afgeleide) waardering van een deelneming via de onderliggende activa, verplichtingen en vermogensposities op basis van:

a de nettovermogenswaarde; of

b de equity-methode.

Bij directe waardering van een deelneming tegen de aanschafprijs is de eventueel betaalde goodwill in de waardering verdisconteerd - de goodwill verschijnt dan niet afzonderlijk op de balans. Rechtstreekse waardering tegen actuele en tegen reële waarde zijn weliswaar mogelijk volgens het Nederlandse jaarrekeningenrecht, maar worden in de praktijk weinig toegepast. De reële waarde is het bedrag dat zou worden betaald bij een transactie tussen onafhankelijke partijen. De actuele waarde kan worden ingevuld door de reële waarde, maar kan ook door de intrinsieke waarde op basis van de beurswaarde worden vastgesteld.

Bij de nettovermogenswaarde wordt de deelneming gewaardeerd tegen het bedrag waarvoor de activa, verplichtingen en de vermogenspositie per saldo in de balans van een overnemer zouden zijn opgenomen, dat wil zeggen indien hij niet de aandelen maar de activa en verplichtingen zou hebben overgenomen. De equitymethode is een variant op de nettovermogenswaarde die wordt gebruikt bij toepassing van de International Financial Reporting Standards.

De VEB voerde onder meer aan dat de waarde van de deelneming te laag werd voorgesteld. Volgens de VEB moet de nettoschuld bij de waarde (de kostprijs) van de deelneming worden opgeteld. De waarde is dan niet $\$ 7,2$ miljard, maar $\$ 9,7$ miljard. ${ }^{38}$ In geen enkele van de vorenstaande waarderingsmethoden wordt de nettoschuld echter bij het geïnvesteerde bedrag opgeteld. Kapitaal verschaffen is een centraal element van een deelneming en dat gaat niet verder dan de investe- 
Enkelvoudige balans van de overnemende vennootschap

\begin{tabular}{lrll}
\hline activa & \multicolumn{3}{l}{ passiva } \\
\hline$-\quad$ materiële vaste activa & $€ 100$ & - eigen vermogen & $€ 50$ \\
$-\quad$ vlottende activa & $€ 50$ & $-\quad$ voorzieningen & $€ 10$ \\
& & - schulden op lange & $€ 40$ \\
& & & termijn \\
& & & schulden op korte \\
totaal: & $€ 150$ & totaal: & $€ 50$ \\
\hline
\end{tabular}

ring - kapitaalverschaffing - door Mylan zelf. Er bestaat geen regel die een dergelijke wijze van waardering voorschrijft.

\subsection{De weergave van de deelneming in de geconsolideerde balans}

Bij de waardering van een deelneming in een geconsolideerde balans wordt als het ware 'door de aandelen heen gekeken' naar de achterliggende activa en verplichtingen die met het kapitaalbelang zijn verworven. Vanuit de groep beschouwd bestaat er geen deelneming, louter de activa en verplichtingen van die deelneming. In dat geval is dus niet de waarde van de deelneming, maar zijn de achterliggende activa, verplichtingen en de betaalde goodwill ${ }^{39}$ relevant. De VEB noemde als voorbeeld dat een deelneming van $€ 1$ grote gevolgen kan hebben voor de geconsolideerde balans. ${ }^{40}$ Onbedoeld lijkt in de gevoerde discussie dan ook de wijze waarop de deelneming uiteindelijk in de geconsolideerde balans verschijnt een rol te spelen. De discussie komt waarschijnlijk voort uit het feit dat twee niet-samenhangende posten aan elkaar worden gerelateerd: de waarde van de deelneming en de waarde van de activa volgens de geconsolideerde balans.

De weergave van de deelneming in de geconsolideerde balans is namelijk een andere dan (enkel) de waarde van die deelneming in de enkelvoudige balans - en is er zelfs nauwelijks aan gerelateerd. Bij de conversie (consolidatie) van de deelneming naar de geconsolideerde balans worden alle activa en verplichtingen van die deelneming aan de bestaande activa en verplichtingen op de geconsolideerde balans toegevoegd. Er zijn twee stadia te onderkennen bij de verwerving en verwerking van de deelneming, namelijk bij het verwerken van de koop in de enkelvoudige balans van de moeder, en vervolgens bij het opstellen van de geconsolideerde balans. Het volgende voorbeeld illustreert dit, waarin de enkelvoudige balansen van een vennootschap die een andere vennootschap volledig wil overnemen en van de te verwerven deelneming als volgt zijn samengesteld:

39 Dit is de uitbreiding van de economische beschikkingsmacht over de bedrijfsmiddelen: de activa en de waarde van de bedrijfsmiddelen die niet afzonderlijk kunnen worden geactiveerd (goodwill).

40 Zie brief van 10 maart 2016 van de VEB aan Mylan. 
Enkelvoudige balans van de te verwerven deelneming

\begin{tabular}{llll}
\hline activa & \multicolumn{2}{l}{ passiva } & \\
\hline$-\quad$ materiële vaste activa & $€ 40$ & - eigen vermogen & $€ 20$ \\
$-\quad$ vlottende activa & $€ 20$ & - voorzieningen & $€ 10$ \\
& & - schulden op lange & $€ 10$ \\
& & & termijn \\
& & schulden op korte & $€ 20$ \\
totaal: & $€ 60$ & totaal: & $€ 60$ \\
\hline
\end{tabular}

Enkelvoudige balans van de moedervennootschap na de overname

\begin{tabular}{|c|c|c|c|}
\hline activa & & passiva & \\
\hline $\begin{array}{ll}- & \text { immateriële vaste } \\
\text { activa }\end{array}$ & $€ 40$ & - $\quad$ eigen vermogen & $€ 50$ \\
\hline _ $\quad$ materiële vaste activa & $€ 100$ & - voorzieningen & $€ 10$ \\
\hline - financiële vaste activa & $€ 20$ & $\begin{array}{ll}\text { - } & \text { schulden op lange } \\
& \text { termijn }\end{array}$ & $€ 100$ \\
\hline - vlottende activa & $€ 50$ & $\begin{array}{ll}\text { - } & \text { schulden op korte } \\
& \text { termijn }\end{array}$ & $€ 50$ \\
\hline totaal: & $€ 210$ & totaal: & $€ 210$ \\
\hline
\end{tabular}

De overnemende vennootschap verwerft de deelneming voor $€ 60$ en waardeert de deelneming (die ook kwalificeert als groepsmaatschappij) tegen nettovermogenswaarde. De nettovermogenswaarde van de deelneming is $€ 20$ (het eigen vermogen van de deelneming); ${ }^{41}$ de betaalde goodwill is $€ 60-€ 20=€ 40$ (de koopprijs min de nettovermogenswaarde). Deze overname kan op verschillende wijzen worden gefinancierd: door middel van een aandelenemissie of het aantrekken van een langetermijn(obligatie)lening, door gebruik te maken van bestaande liquide middelen, of door een combinatie hiervan. Stel dat de moedervennootschap de overname geheel financiert met behulp van een langetermijnlening. Dan ziet de balans na de overname er als volgt uit:

\section{- Toelichting:}

Aan de actiefzijde zijn de goodwill ( $€ 40)$ - immateriële vaste activa - en de deelneming ( $€ 20)$ - financiële vaste activa - aan de activa toegevoegd.

Aan de passiefzijde is de langetermijnlening ( $€ 60)$ aan de post schulden op lange termijn toegevoegd.

Art. 2:107a onder c BW relateert de waarde van een deelneming echter niet aan de activa op de enkelvoudige balans, maar (indien aanwezig) aan de activa op de geconsolideerde balans. Hier doet zich het probleem voor dat de deelneming - als

41 Ervan uitgaande dat er geen aanpassing van de waardering van de activa en verplichtingen van de deelneming aan de grondslagen van de moeder hoeft plaats te vinden. 


\section{Geconsolideerde balans na de overname (moedervennootschap en deelneming)}

\begin{tabular}{lrlr}
\hline activa & \multicolumn{2}{l}{ passiva } & \\
\hline$-\quad$ immateriële vaste & $€ 40$ & - & eigen vermogen \\
activa & $€ 140$ & $-\quad$ voorzieningen & $€ 50$ \\
$-\quad$ materiële vaste activa & $€ 70$ & $-\quad$ schulden op lange & $€ 20$ \\
$-\quad$ vlottende activa & & & termijn \\
& & & schulden op korte \\
& & termijn & $€ 70$ \\
totaal: & $€ 250$ & totaal: & $€ 250$ \\
\hline
\end{tabular}

afzonderlijke activum - op de geconsolideerde balans verdwijnt. Bij consolidatie wordt de deelneming vervangen door de achterliggende activa en verplichtingen. De geconsolideerde balans ziet er dan als volgt uit: ${ }^{42}$

\section{Toelichting:}

Aan de actiefzijde zijn de financiële vaste activa ( $€ 20)$ vervangen door de achterliggende componenten van het vermogen van de deelneming: dit zijn de activa van de deelneming ( $€ 60)$ : materiële vaste activa $(€ 40)$ en vlottende activa $(€ 20)$. Deze componenten zijn opgeteld bij de bestaande balansposten.

Ook aan de passiefzijde zijn de balansposten vervangen door de achterliggende componenten van het vermogen van de deelneming: dit zijn een deel van de passiva van de deelneming ( $€$ 40): voorzieningen ( $€ 10)$, schulden op lange termijn $(€ 10)$ en schulden op korte termijn ( $€ 20)$ van de deelneming; aan de passiefzijde is ook de langetermijnlening ( $€ 60)$ waarmee de moedervennootschap de overname heeft gefinancierd, verwerkt in de post schulden op lange termijn.

De verwerving van de deelneming heeft een veel groter effect op de groepsactiva (en ook de groepspassiva) tot gevolg dan alleen de waarde van de deelneming als individueel actief. De waarde van de deelneming en de groepsactiva zijn dan ook geen aan elkaar gerelateerde grootheden: de waarde van de deelneming (inclusief de goodwill) is $€ 60$, maar de waarde van de activa op de geconsolideerde balans stijgt door de overname met $€ 100$ naar $€ 250$. Dit komt overeen met de stelling van de VEB: zelfs indien een deelneming wordt verkregen tegen $€ 1$ kan de economische beschikkingsmacht over de activa toch significant toenemen. Dit illustreert dat art. 2:107a lid 1 onder c BW twee begrippen aan elkaar koppelt die niet een-op-een aan elkaar zijn gerelateerd: enerzijds de prijs die voor de deelneming wordt betaald, en anderzijds (als er een geconsolideerde balans is) de waarde van

42 De solvabiliteit (eigen vermogen gedeeld door totaal vermogen) is in de uitgangssituatie: 50/150 $=1 / 3$, na verwerving en consolidatie van de deelneming: $50 / 250=1 / 5$. De oorzaak van de stijging van de verplichtingen is tweeledig: enerzijds de lening waarmee de overname is gefinancierd ( $€ 60)$, anderzijds de verplichtingen van de deelneming ( $€ 40)$ die aan de verplichtingen van de groep zijn toegevoegd. De term nettoschuld die door de VEB wordt gehanteerd, beïnvloedt noch de waarde van de deelneming, noch de solvabiliteit. 
de deelneming volgens de geconsolideerde balans. De reden hiervoor is dat zowel de activa van de deelneming als de betaalde goodwill worden toegevoegd aan de activa in de geconsolideerde balans.

\section{Conclusie en voorstel tot herformulering}

In paragraaf 2 is bij de wetshistorische verhandeling van zowel art. 2:164/274 BW als art. 2:107a BW geconcludeerd dat motiveringen ontbreken of ondeugdelijk zijn. Vrijwel nergens wordt de achterliggende doelstelling van de goedkeuring van bepaalde bestuursbesluiten aangegeven. De Mylan/Meda-casus werpt - mede in het licht van de wetshistorische verhandeling van zowel art. 2:164/274 BW als art. 2:107a BW - een licht op de mogelijke interpretaties en complicaties van het laatste wetsartikel. Identiteit en karakter van een onderneming zijn moeilijk grijpbare begrippen en kennen vele dimensies. Dit heeft wellicht geleid tot de niet goed doordachte tekst van art. 2:107a lid 1 onder c BW. In onderdeel c van art. 2:107a lid 1 BW worden twee niet met elkaar samenhangende begrippen aan elkaar gerelateerd: de waarde van de deelneming (de prijs die voor de deelneming wordt betaald) en de waarde van de activa volgens de geconsolideerde balans.

Dit pleit voor een herformulering van art. 2:107a lid 1 onder c BW die tegemoetkomt aan de (door de VEB aangevoerde) complicatie dat ook een (zeer) geringe prijs die voor een deelneming wordt betaald grote gevolgen kan hebben voor de geconsolideerde balans. Die herformulering houdt er rekening mee dat de waarde van een deelneming niet altijd de prijs mag zijn die voor de deelneming wordt betaald, maar gebaseerd moet zijn op de onderliggende activa als de verwerking van de deelneming in de geconsolideerde balans daartoe aanleiding geeft. Indien de verwijzing naar de geconsolideerde balans (als alternatief voor de enkelvoudige balans) in art. 2:107a lid 1 onder c BW reële betekenis moet hebben, zou deze bepaling als volgt kunnen luiden:

'c. het nemen of afstoten van een deelneming in het kapitaal van een vennootschap ter waarde van ten minste een derde van het bedrag van de activa volgens de balans met toelichting of, indien de vennootschap een geconsolideerde balans opstelt, volgens de geconsolideerde balans met toelichting volgens de laatst vastgestelde jaarrekening van de vennootschap, door haar of een dochtermaatschappij; indien de vennootschap een geconsolideerde balans opstelt, geldt als waarde van de deelneming ten minste de waarde van de (onderliggende activa van de) deelneming zoals de deelneming volgens de door de vennootschap gehanteerde waarderingsgrondslagen in de geconsolideerde balans zal worden verwerkt (na het nemen van de deelneming) of is verwerkt (voorafgaand aan het afstoten van de deelneming), inclusief de goodwill'.

Deze formulering houdt rekening met de omstandigheid dat de waarde van een deelneming volgens de enkelvoudige balans en volgens de geconsolideerde balans een verschillende inhoud hebben, en voorkomt dat de verwijzing naar de geconso- 
Het goedkeuringsrecht voor deelnemingen in art. 2:107a (en 2:164/274) BW: Mylan/Meda revisited

lideerde balans ertoe leidt dat het nemen of afstoten van een deelneming onbedoeld buiten het bereik van art. 2:107a lid 1 onder c BW valt. 